\title{
The Image of Ružena Maturová in the Iconography Collection of the Bedrich Smetana Museum
}

\section{Jana Plecitá}

Abstract: The article summarises the results attained so far through research and expert processing of the photographs held in the iconography collections of the Bedřich Smetana Museum. It provides information about Růžena Maturová (1869-1938) including previously unpublished details about the period of her life after the end of her career as an opera singer at the National Theatre in Prague (1910-1938), concerning Maturová's performing in silent film (1920-1922), her work in healthcare services (1914-1920), and her sociocultural activities in support of retired soloists from the National Theatre in Prague (at the Na Slovanech Cinema, 1920-1938). The subject matter of the study is a photo album titled R. Maturová. In many cases, comparisons of the photographs from this album with other available sources have enabled the recognition of persons not previously identified in portraits, more exact determination of dating and provenience, and the identification of photography studios.

Key words: Historical photography, Růžena Maturová, Langhans, Josef Fiedler, Conrad Ruf, Jan Mieczkowski, Josef A. Neuman, Václav Vlasák, Karel Váňa, František Šlechta, National Theatre in Prague, Emmy Destinn, Na Slovanech Cinema, Czech feature films

The Bedřich Smetana Museum (MBS) boasts a rich collection of photography containing pictures of various kinds. Since the museum came into existence, it has been expanding its collections in part through donations. If we focus on portrait photography that consists mainly of visiting cards and cabinet photographs, we see that during the museum's first decades, besides portraits of Bedřich Smetana, his family, and other persons, likenesses of opera singers were also collected successfully, showing them not only in "civilian" portraits, but also wearing costumes of roles from operas by Smetana and others.

Růžena Maturová (1869-1938) is currently the focus of research and of the scholarly processing of the photography collection from the iconography collections, and she is regarded as one of the greatest singers in the history of opera at the National Theatre in

This work is financially supported by the Ministry of Culture of the Czech Republic (DKRVO 2019-2023/22.I.a, 00023272). 
Prague. Just three months after Růžena Maturovás death, the photography collection at the MBS obtained three extensive albums and seventeen individual photographs, which were turned over to it in May 1938 by the notary Ladislav Kuna as the singer's bequest to the museum. ${ }^{1}$ In addition, in her will, ${ }^{2}$ Růžena Maturová left the Central Union of Czech Actors a land lot in the Prague neighbourhood Trója, and to the Modern Gallery (today the National Gallery in Prague) she left a portrait by Max Švabinský. ${ }^{3}$ The first album of photographs, which is the subject of this article, bears the title R. Maturová. ${ }^{4}$ Another two albums are furnished with the titles Members of the Opera and Ballet of the National Theatre and Members of the Drama Company of the National Theatre. ${ }^{6}$ Even earlier, in 1931 Maturová donated six photographs to the Smetana Museum, ${ }^{7}$ in 1934 two cabinet cards $^{8}$ (in the roles of Mařenka and Libuše), and in 1937 Bedřich Smetana's visiting card with an inscription in his hand and two programmes for Prodaná nevěsta (The Bartered Bride) in Berlin in 1893. The artist's love for Smetana is possibly the explanation for her bequest of these materials to the Bedřich Smetana Museum. The museum collection also contains other photographs, postcards, and prints of portraits of the singer, a bound album with photographs of artists of the National Theatre in Prague (ND), ${ }^{10}$ and a portrait by Alex Adolf Jelínek of Maturová in costume as Libuše. ${ }^{11}$

Work on this research has resulted in a catalogue ${ }^{12}$ that contains detailed information only for the album titled R. Maturová, but the other two albums figure in the overall catalogue. When identifying unknown persons in the portraits, photographic studios, dating, and provenience, I worked with the aforementioned three albums and with data from the photographic collections of the National Museum. ${ }^{13}$ I also drew on data provided to me by the

1) NM-ČMH-MBS acquisition no. F 106, registered on 31 May 1938. Maturová died on 25 February. Enclosed is a letter, in which Kuna reports: "I am taking the liberty of handing over the albums bequeathed to you by Mrs. Růžena Maturová-Jílková, member emeritus of the opera of the National Theatre in Prague, concerning which I sent you information in a letter dated 19 May of this year."

2) Odkazy pí. R. Maturové (Bequests of Mrs R. Maturová), Národní listy, vol. 78, no. 57, Praha 27 Feb. 1938, p. 3.

3) Oil on canvas, $85 \times 84 \mathrm{~cm}$, National Gallery Prague, inv. no. 03602 .

4) NM-ČMH-MBS inv. no. 3212/1-236.

5) NM-ČMH-MBS inv. no. 3213/1-319.

6) NM-ČMH-MBS inv. no. 3217/1-247.

7) NM-ČMH-MBS inv. no. 1929-1932, 2426, 2427.

8) NM-ČMH-MBS inv. no. 1933, 1934.

9) NM-ČMH-MBS inv. no. S 217/1746/4, programmes, acquisition no. F 9.

10) NM-ČMH-MBS inv. no. 4229/1-519.

11) This is a gift from her nephew Dr. Alois Matura. Oil on canvas, $77 \times 63.5 \mathrm{~cm}$, NM-ČMH-MBS M 770. The painting was based on the photograph NM-ČMH-MBS inv. no. 1929, which originally belonged to Maturová.

12) This is not included with the article for reasons of space. Accessed from: https://www.nm.cz/o-nas/ odborna-cinnost\#katalogy

13) Czech Museum of Music - B. Smetana Museum (NM-ČMH-MBS), Czech Museum of Music - Department of Music History (NM-ČMH-HHO), Czech Museum of Music - A. Dvořák Museum (NM-ČMH-MAD), Collection of the National Museum - Theatre Department. 
Langhans Archiv Praha (LAP), ${ }^{14}$ the Archives of the National Theatre (AND), ${ }^{15}$ the National Film Archive (NFA), and the periodicals Národní album, ${ }^{16}$ Zlatá Praha, ${ }^{17}$ Světozor, ${ }^{18}$ and Český svět. ${ }^{19}$ As far as biographical data are concerned, I relied on the only existing monograph by Artuš Rektorys ${ }^{20}{ }^{2}$ which was published while Maturová was still living, so the credibility of the information it provides can be regarded as relatively high. The study offers an overview of the artist's lifetime of artistic activities, relying in part on information from Artuš Rektorys, ${ }^{21}$ but mainly on the facts that can be ascertained from the photographs: a complete listing of opera roles, an overview of all theatrical and concert performances on German stages and in Russia (Saint Petersburg, Moscow), Warsaw, Belgrade, the USA (New York, Chicago, Cedar Rapids, Cleveland, Omaha), and of course mainly at the National Theatre in Prague ${ }^{22}$ and on other Czech stages.

\section{The photographic album R. MATUROVÁ}

The dimensions of the photo album are $53 \times 33 \times 7 \mathrm{~cm}$. The cover is dark brown leather decorated with gold lines around the perimeter of the cover, and there is a gold embossed text and a lyre on the spine. It contains 63 leaves and front and back endsheets. A total of 239 photographs and printed reproductions are glued on one side of 42 grey-green pieces of heavier-weight cardboard and 15 brick-red pieces of cardboard; 6 pieces of cardboard bear no photographs. The paper is very brittle and fragile. The individual pieces of cardboard have a lining made of thin, light-coloured paper. In spite of this, over time more than half of the photographs have left marks on the opposite side of the cardboard. Nonetheless, the photographs are in good condition overall.

14) At LAP, 18 glass negatives of Maturová have been preserved.

15) At AND, there is an album bound in satin covers containing larger cabinet photographs of Maturová.

16) -Hda- [HEJDA, František Karel]: Růžena Maturová, in: Národní album. Sbírka podobizen a životopisů českých lidí prací a snahami vynikajících i zasloužilých (The National Album. A collection of likenesses and biographies of Czech People, Work, and Outstanding and Meritorious Efforts), Jos. R. Vilímek, Praha 1899, ill. J. Filipi, picture p. 11, biography p. 17.

17) O. K.: Paní Růžena Maturová (Mrs. Růžena Maturová), Zlatá Praha, vol. 12, no. 12, Praha 1 Feb. 1895, p. 142 (Maturová depicted in the role of Santuzza, p. 133); Tři postavy poesie Puškinovy (Three Characters from the Poetry of Pushkin), Zlatá Praha, vol. 16, no. 30, Praha 2. 6. 1899, p. 356 (Maturová depicted in the role of Máša, studio of F. J. Langhans).

18) -j.: Prodaná nevěsta v Berlíně (The Bartered Bride in Berlin), Světozor, vol. 27, no. 34, Praha 7 July 1893, pp. 407-408; -j.: Rủžena Maturová, Světozor, vol. 30, no. 25, Praha 1 May 1896, p. 298 (Maturová depicted, studio of Jan Mulač, p. 289).

19) REKTORYS, Artuš: Naše umělkyně Růžena Maturová (Our Artist Růžena Maturová), Český svět, vol. 1, no. 8, Praha 17 Feb. 1905, p. 258 (Maturová depicted in the role of Libuše, studio of V. Donát, p. 257).

20) REKTORYS, Artuš: Růžena Maturová, O. Girgal, Praha 1936 (hereinafter REKTORYS). The monograph is supplemented by fourteen photographic reproductions of Maturová in roles, two civilian photographs, and a portrait of Max Švabinský.

21) Overview of roles by REKTORYS, op. cit. in footnote no. 20, pp. 105-131. In some cases, roles have been identified where Rektorys give no information. The composer of Die Königsbraut is actually Robert Fuchs; Rektorys incorrectly gives Richter, who was the conductor, and the composer of the operetta Kapitán Fracasse (Capitaine Fracasse) is actually Rudolf Dellinger; Rektorys incorrectly lists Richard Genée, who was the librettist. 22) She sang at the National Theatre (ND) from 19 Aug. 1892 to 27 Aug. 1893 as a guest and from 14 Sept. 1893 to 7 Feb. 1910 as an ensemble member. 
The photographs are numbered continuously as follows: 1-80, 80a, 81, 81a, 82, 82a, 83-117, 118a, 118b, 119-215, 215a, 216, 216a, 217-236. The actual number of photographs is therefore 242. The album was complete when it was added to the collection of the MBS. ${ }^{23}$ Unfortunately, three of the photographs are now missing. ${ }^{24}$ The first was a photograph of Maturová in costume as Libuše from 1898 [1], ${ }^{25}$ and the other two from the Langhans studio showed the singer in costume as Rusalka $[28,76]$. Some of the photographs in the album have inscriptions by Růžena Maturová (in pen or pencil) with information about the place, role, dating, or details about the depicted persons. The dimensions vary and do not correspond to the information in the inventory book. The photographs do not always proceed chronologically. The photographs in the catalogue are sorted by the following criteria: in costume by role (opera: 70, drama: 1), civilian dress chronologically (Maturová: 48, groups of people: 31), other persons (16), film (63), buildings (6), postcards (3), miscellaneous (1), and missing photographs (3).

Just under half of the photographs in the album from Prague studios are from the companies Langhans ${ }^{26}$ and Josef Fiedler. ${ }^{27}$ Among foreign studios, Conrad Ruf's in Mannheim is represented by twenty photographs. ${ }^{28}$ The studios of Jan Mieczkowski (Warsaw), ${ }^{29}$ Josef A. Neuman (Prague), ${ }^{30}$ Václav Vlasák (České Budějovice), ${ }^{31}$ and the semiamateur photographer Karel Váňa (Prague) appear in single instances. ${ }^{32}$ The first known portrait is a photograph taken in 1889 at František Šlechta's studio [3]..$^{33}$

23) This can be deduced from the entries in the inventory book on pp. 164-170, where there are brief descriptions including dimensions.

24) They were lost between 1975 and 1984. In the inventory book there are inspection rubberstamp impressions rev. 52 and rev. 75, then in the year of the next inspection, 1984, there is no rubberstamp.

25) The picture is printed in Vilímek's art nouveau Národní album (see footnote no. 16) and in the journal Český svět (see footnote no. 19). It is documented by two cabinet photos from the studio of J. Tomáš, Praha (NMČMH-MBS F 4675/1 and NM-ČMH-MBS inv. no. 1934). The numerals in square brackets give the ordering of photographs in the album.

26) The company was in business from ca. 1884 to 1919 at the address Praha, Vodičkova 37. SCHEUFLER, Pavel: Fotografickéateliéry na území Koruny české (Photographic Studios in the Lands of the Bohemian Crown), Národní památkový ústav (National Heritage Institute), Praha 2017, p. 147 (hereinafter SCHEUFLER).

27) Studio at the address Praha, Václavské náměstí (Wenceslas Square) 24 from 13 July 1893 to 1 Feb. 1921. See SCHEUFLER, op. cit. in footnote no. 26, p. 95.

28) Mannheim, Breitestrasse M 1.4. Accessed from: http://www.fotorevers.eu/de/fotograf/Ruf/55/[accessed on 27 Mar. 2020].

29) Photographic studio of Jan Mieczkowski in his own house, 1853-1889, Varsovie, Nowo Miosowa 1. Accessed from: http://www.fotorevers.eu/fotograf/Mieczkowski/1284/ [accessed on 27 Mar. 2020].

30) The studio was in Prague on the Karlova Street next to the St Wenceslas Credit Union. OCELÁK, Radek: Katalog české vizitkové fotografie (Catalogue of Czech Photography on Visiting Cards), Rýmařov 2020. Version 1.2 (published on 18 Mar. 2020). Accessed from: http://podoby-predku.cz/katalog-ceske-vizitkovefotografie/ [accessed on 27 Mar. 2020].

31) In 1907 Václav Vlasák bought the photography studio from Antonín Pech. It was located on the corner of Žižkova Boulevard (Schmelingova at the time) and Senovážné náměstí (square).

32) He was a member of the opera and drama ensembles of the ND. He photographed a number of his colleagues.

33) Praha, Žitná Street 12. The studio was identified from the photograph NM-ČMH-HHO F 535. 
Among the pictures of Prague provenience, Jan Mulač and Jan Tomáš are not represented, for example, although Maturová had pictures taken by them. ${ }^{34}$ A full $65 \%$ of the studios have been localised, although only 10 of the photographs bear a designation of the studio. The second half of the photo album consists of amateur photographs and still shots from films.

In Maturovás album, just under 30 photographs involve Czech operas, while nearly 40 involve foreign repertoire. Far from all of the roles she sang in her lifetime are represented. For the total of 89 roles, the album contains 25, i.e. nearly a third (see the table). Most of the depicted roles are from her engagement at the National Theatre in Prague (80\%).

\section{List of roles in reference to the album of Růžena Maturová}

\begin{tabular}{|l|l|l|l|l|l|}
\hline Role & Composer & Opera, operetta & Theatre & $\begin{array}{l}\text { Photography } \\
\text { studio }\end{array}$ & $\begin{array}{l}\text { Photo number } \\
\text { in the album }\end{array}$ \\
\hline Anežka & B. Smetana & Dvě vdovy & ND & K. Váňa & 130 \\
\hline Armida & A. Dvořák & Armida & ND & Langhans & 111,112 \\
\hline Desdemona & G. Verdi & Otello & Mannheim & [C. Ruf] & 12, 13, 14, 19 \\
\hline Desdemona & G. Verdi & Otello & ND & J. Fiedler & $43,64,65,66$ \\
\hline Eva & J. B. Foerster & Eva & ND & Langhans & $91,94,105$ \\
\hline Hedy & Zd. Fibich & Hedy & ND & J. Fiedler & $75,80,81$ \\
\hline Libuše & B. Smetana & Libuše & ND & Langhans & 86 \\
\hline Manon Lescaut & G. Puccini & Manon Lescaut & ND & Langhans & $82 a$ \\
\hline Mařenka & B. Smetana & Prodaná nevěsta & ND & Langhans & $2,21,23,78$ \\
\hline Marguerite & Ch. Gounod & Faust & Teplice & unidentified & 4 \\
\hline Maruše & Ant. Smareglia & Nozze istriane & ND & J. Fiedler & 40,73 \\
\hline Máša & Ed. Nápravník & Dubrovsky & ND & J. Fiedler & 39,59 \\
\hline Máša & Ed. Nápravník & Dubrovsky & ND & Langhans & 57, 58, 60 \\
\hline Micaëla & Ch. Bizet & Carmen & Mannheim & C. Ruf & $8,18,20$ \\
\hline Milada & B. Smetana & Dalibor & ND & Langhans & $83,95,96$ \\
\hline Ortrud & R. Wagner & Lohengrin & ND & Langhans & $37,87,88,125$ \\
\hline Rachel & J. F. Halévy & La Juive & ND & K. Váňa & 127,129 \\
\hline Rusalka & A. Dvořák & Rusalka & ND & Langhans & $106,107,108$ \\
\hline Santuzza & P. Mascagni & Cavalleria rusticana & Mannheim & [C. Ruf] & 6,33 \\
\hline Š́rka & Zd. Fibich & Š́rka & ND & Langhans & $89,90,131$ \\
\hline
\end{tabular}

34) Role of Milada (Smetana, Dalibor), J. Mulač, NM-HM, Theatre Department H6E-38F485; role of Amelia (Verdi, Un ballo in maschera), J. Mulač, NM-HM, Theatre Department H6E-38F487; role of Libuše (Smetana, Libuše), J. Tomáš, NM-ČMH-MBS inv. no. 1934. 


\begin{tabular}{|l|l|l|l|l|l|}
\hline Role & Composer & Opera, operetta & Theatre & $\begin{array}{l}\text { Photography } \\
\text { studio }\end{array}$ & $\begin{array}{l}\text { Photo number } \\
\text { in the album }\end{array}$ \\
\hline Tosca & G. Puccini & Tosca & ND & Langhans & $\begin{array}{l}\text { 100, 101, 102, } \\
\text { 103, 104 }\end{array}$ \\
\hline Undine & A. Lortzing & Undine & Mannheim & [C. Ruf] & 9,11 \\
\hline Valentine & G. Meyerbeer & Les Huguenots & ND & J. Fiedler & 29, 41, 71, 92 \\
\hline Viktorka & Ant. V. Horák & Babička & ND & Langhans & 109,110 \\
\hline Vlasta & Ot. Ostrčil & Vlasty skon & ND & Langhans & $97,98,99$ \\
\hline
\end{tabular}

\section{Moments of Růžena Maturová's life pieced together from the album}

Růžena Maturová attended a singing school run by the Loewes, a husband and wife who were sought-after vocal teachers in Prague. Maturová was one of their most important pupils along with Emmy Destinn (1878-1930), who was Maturová's admirer and friend. ${ }^{35}$ Maturová pasted a photograph of her teacher Marie Loewe-Destinn in her album [85]. ${ }^{36}$ Her first job was at the municipal theatre in Teplice. ${ }^{37}$ After Teplice came an engagement at the Nationaltheater in Mannheim, ${ }^{38}$ and that also meant a great deal for Maturová's private life. It was there that she met her first husband, a member of the court drama ensemble, Ludvík Schreiner (1864-1896). ${ }^{39}$ With his death shortly after their marriage, Maturová lost a friend and a person of noble character. The album contains two pictures of them together, from before their marriage in 1891 [10] ${ }^{40}$ and from 1895 [62]. At the request of the general manager of the National Theatre in Prague F. A. Šubert, Maturová bade farewell to Mannheim in early 1893.

Before Maturová began studying her own roles at the National Theatre, she took part in a memorable Berlin production of The Bartered Bride in the summer of 1893, from which she came away with not only valuable success, ${ }^{41}$ but also the inception of her admiration

35) While still named Kittlová, she dedicated a little bundle of poems titled Hrstka rýmů (A Handful of Rhymes) to Maturová in 1896. She dedicated a photo of herself in costume as Milada "To Mrs. Rǔžena Maturová with friendly admiration, Emma Destinnová 1912”; see NM-ČMH-MBS inv. no. 3213/269.

36) The mezzo-soprano Marie von Dreger Loewe-Destinn (1837-1921) in the role of Balkis (Gounod, La reine de Saba).

37) From October 1889 to the end of 1890.

38) April and September 1890, September 1890 to January 1893. She appeared in 24 operatic roles and in 2 operetta roles.

39) Schreiner was at the Mannheim theatre from 1870 to 1896 . When he died, Maturová was already a soloist at the ND.

40) The wedding took place on 18 October 1892 in Mannheim.

41) "Concerning the alternations in the casting of roles, we would just also mention that lovely Monday evening [3 July 1893], when Mrs. Maturová and Mr. Burian performed together, and some passages, especially the duet Vèrné milováni (Faithful love), only now achieved their valid form thanks to the precise performance." Prodaná nevěsta v Berlínè (The Bartered Bride in Berlin), Světozor, vol. 27, no. 34, Praha 7July 1893, p. 408. Ibid on p. 407 is photography of the performers by F. J. Langhans: Dopschová (Háta), Karel Burian (Jeník), Emanuel Kroupa (Krušina), Rủžena Maturová (Mařenka), Hašek (Mícha), Martin Klein (Vašek), Josef Arden (Kecal), and Vítězslava Kratochvílová (Ludmila). 
for Smetana's music, which then became the greatest love of her life. ${ }^{42}$ The general manager of the Brno theatre Adolf Baumann ${ }^{43}$ employed Czech soloists and began a series of performances at the Unter den Linden theatre. $^{44}$ For this purpose, he chose The Bartered Bride, which had gained popularity at the International Exhibition of Music and Theatre in Vienna in 1892. Baumann secure the services of a good conductor, František Jílek (1865-1911), who was briefly the second husband of Růžena Maturová. ${ }^{45}$ Preserved in the photo album are two pictures of them together from 1907 [123, 124]. At the National Theatre, Maturová first sang the role of Mařenka in October $1893 .{ }^{46}$ Already during her first year performing there, she also sang the role of Milada, which accounts for the greatest number of performances in her repertoire, amounting to nearly one fifteenth of all of her appearances. In the MBS's collection of three-dimensional objects, there are even preserved theatrical costumes that Maturová wore when singing

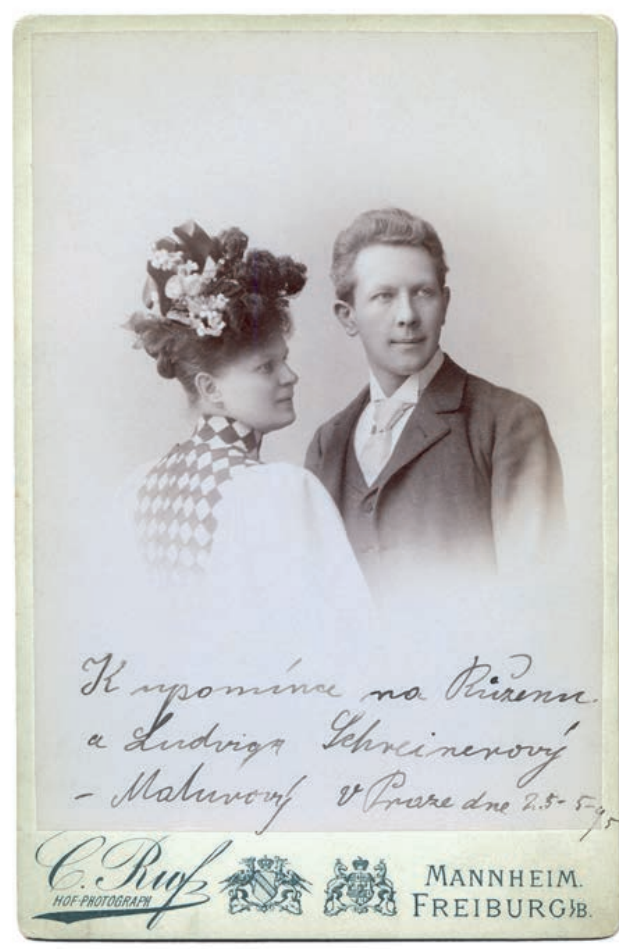

Růžena Maturová and Ludvík Schreiner / Růžena Maturová a Ludvík Schreiner Photograph, Conrad Ruf, Mannheim, 1895 / Fotografie, Conrad Ruf, Mannheim, 1895 NM-CMH-MBS inventory / inv. č. no. 7044

42) She sang six Smetana roles in the course of her career: Anežka, with which she began her Prague engagement in Sept. 1893, followed by Mařenka, Milada, Krasava, Libuše, and Vendulka. Her wish to sing the role of Blaženka remained unfulfilled.

43) Baumann was planning to tour all of Europe and America with The Bartered Bride, Hubička (The Kiss), and Dalibor.

44) Stage director: Josef Šmaha, conductors: Adolf Čech and František Jílek, choreography: Augustin Berger; Robert Holzer's stage design and the ballet were brought in from Prague. "The planned eight-week tour, which was supposed to have continued in Paris and especially in America, wound up as a fiasco after a few repeat performances because of poor organisation, bad scheduling decisions, and the bad [!] translation of The Bartered Bride." (The translation was by Max Kalbeck; in German-speaking countries, it is still regarded, together with a more modern translation by Kurt Honolka, as the best, and it is therefore the most frequently performed version.) Accessed from: http://encyklopedie.idu.cz/index.php/Baumann,_Adolf [accessed on 27 Mar. 2020]. Also PRAŽÁK, Přemysl: Smetanova Prodaná nevěsta (Smetana’s Bartered Bride), Lidová demokracie, Praha 1962, pp. 294-296.

45) The wedding took place in Prague on 23 April 1906.

46) J. B. Foerster wrote about her portrayal of Mařenka in: Národní listy, vol. 33, no. 295, Praha 24 Oct. 1893, p. 4: "[...] it turned out well. The singer brought off a performance with the subtle observation of quite a few vocal and dramatic details, and she proved that she is a creative talent; that is what carries the most weight. Every scene was given appropriate expression, the heartfelt devotion of a loving girl was presented naturally, and the flirtatious scenes with Vašek were brought to life with apt playfulness. Her superb disposition contributed towards the great public success of the others [...]”. 


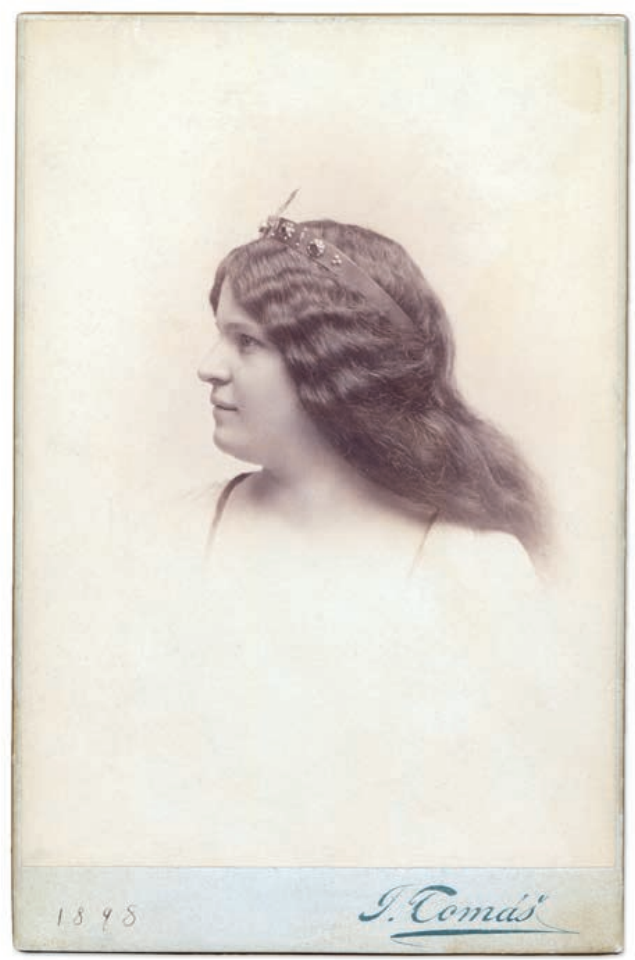

Růžena Maturová in the title role of Smetana's opera Libuše / Růžena Maturová jako Libuše ze stejnojmenné Smetanovy opery

Photograph, Jan Tomášs, Prague, 1898 /

Fotografie, Jan Tomášs, Praha, 1898

NM-CMH-MBS inventory no. / inv. č. 1934 the role of Milada. ${ }^{47}$ What can truly be regarded as a rarity is the documentation of Maturovás portrayal of the role of Milada at the National Theatre in 1900: the MBS collections contain not only photographs, but also stage design elements and threedimensional objects. ${ }^{48}$

In 1897 at the age of 28, Maturová arrived at the role that forever secured her importance to Czech music. Libuše was the highpoint of her artistic career. At her fifth performance on 25 January 1898, Maturová received a silver wreath from the National Theatre Cooperative [146]. ${ }^{49}$ Gustav Salvayre, a French critic and an enthusiastic promoter of Smetana's music in France, called Maturová "Europe's greatest singer". Emmy Destinn declared: "After you, nobody else will do Libuše; you're the best Libuše." Adolf Čech gave her a piano vocal score with a dedication: "To our ideal Libuše for the sake of the kind remembrance of the conductor of Smetana's Libuše in sincere friendship, Ad. Čech." ${ }^{50}$ It was also in that role that she bade farewell to the stage of the National Theatre on 7 February 1910. ${ }^{51}$

Růžena Maturovás only appearance in a drama in the role of maid Róza [235] in the play Introduction to the Dance by Alexandre Dumas père took place on 9 December 1916.

While making a guest appearance in Belgrade in October 1901, Růžena Maturová appeared in concert in the building of the present-day National Theatre [32]. When she visited Serbia, she received the Order of St. Sava, $3^{\text {rd }}$ class, ${ }^{52}$ with which she had herself

47) Bedřich Smetana, Dalibor, funeral costume from Act I: NM-ČMH-MBS dress TP 325, diadem TP 326, and veil TP 327.

48) A blouse has been preserved from the costume of Milada from Act II, NM-ČMH-MBS TP 323 based on the costume design by Karel Štapfer NM-ČMH-MBS Sc 0403.

49) Wreath with the inscription: "To the esteemed artist Růžena Maturová from the Cooperative of the National Theatre in Prague for a wonderful portrayal of Smetana's Libuše.” (REKTORYS, op. cit. in footnote no. 20, p. 45). 50) REKTORYS, op. cit. in footnote no. 20, p. 45.

51) She had invitations printed with the text: "Růžena Maturová expresses her sincere thanks for kind, special remembrance as well as for your kind presence at her farewell performance." NM-HM, Theatre Department H6E-35F17.

52) The Order of Saint Sava was founded in 1883 by Milan Obrenović, King of Serbia. It was awarded for artistic, cultural, and scientific merit. It was also awarded to foreigners. 
photographed several times at Langhans's studio on Vodičkova Street in Prague [77, 79, 128]. We can best see her personal character from the period during and shortly after the First World War, when she served until 1920 as a nurse at the hospital on Karlovo náměstí (square). ${ }^{53}$ There are two photographs from 1915 with Maturová in a nurse's uniform $[150,151]$.

Immediately after the coup d'état in 1918, Maturová devoted all of her energy to obtain licensing for a popular Prague cinema called $\mathrm{Na}$ Slovanech, which was built at the site of the cinema Bio Imperial. ${ }^{54}$ The licence belonged to the Club of the Retired Soloists of the National Theatre in Prague. ${ }^{55}$ The proceeds were to be used as financial support for retired members of the National Theatre. The initiative proved to be successful: thanks to Maturová, the Club of the Retired Soloists of the National Theatre received a full 1 million Czechoslovak crowns. ${ }^{56}$ Preserved in the album are rare photographs of both the cinema building [227] and its interior [159]. ${ }^{57}$ For the first performance, Maturová

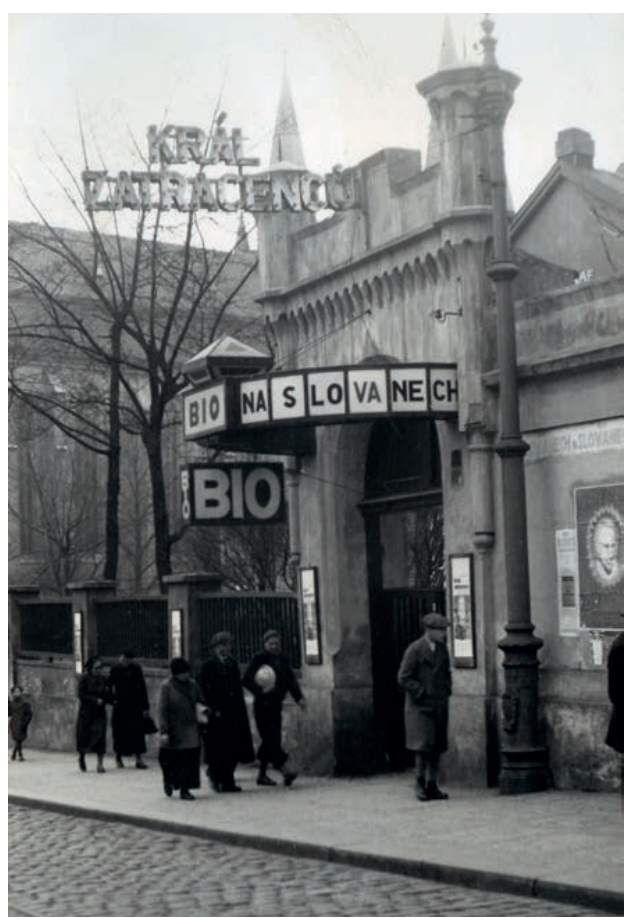

The Prague cinema Na Slovanech / Pražský biograf $\mathrm{Na}$ Slovanech

Photograph, unknown photographer, Prague, [after 1920] / Fotografie, autor neznámý, Praha [post 1920]

NM-ČMH-MBS inventory no. / inv. č. 3212/227

had intended to show a film called Slavná Destinnová v svém domově, v zámku ve Stráži (The Great Destinn at Home in the Castle at Stráž) and to organise the filming of the great

53) Her patients gave her the most beautiful title that can be bestowed out of love, calling her "our mama". (REKTORYS, op. cit. in footnote no. 20, p. 62).

54) Bio Imperial was built in 1911 on the premises of the former cinema Illusion. It was torn down in 1920. A new cinema named $\mathrm{Na}$ Slovanech with 900 seats was built in its place. It was destroyed by an American air raid on 14 February 1945 at the same time as that the towers of the Emmaus Monastery were destroyed. (ŠŤÁBLA, Zdeněk: Data a fakta z dějin čs. kinematografie 1896-1945 (Data and Facts from the History of Czechoslovak Cinematography 1896-1945), vol. 1, Čs. filmový ústav (Czechoslovak Film Institute), Praha 1988, p. 149; hereinafter ŠŤÁBLA).

55) Maturová mentioned the granting of the license in a letter to Emmy Destinn dated 31 Aug. 1920: "A year and a half ago, the Club of Retired Soloists of the National Theatre got a license to run a cinema in order to increase the revenue of its 32 members, deserving elderly artists the drama and opera companies of the National Theatre, ladies and gentlemen with modest pensions, thereby making up for a bit of what they lost during the war." NM-HM, Theatre Department H6E-1900.

56) POSPÍŠIL, Miloslav: Z operního Olympu - Pěvecké legendy 20. století (From Opera’s Olympus - Legendary Singers of the $20^{\text {th }}$ Century), Brána, Praha 2009, p. 75.

57) The photographs of the entrance to the cinema Na Slovanech and of its interior show that the original site was probably adapted, rather than a new building having been erected. See ŠŤÁBLA, op. cit. in footnote no. 54 . 
singer at Stráž,$^{58}$ but that did not take place, unfortunately. In a letter, she confided in Emmy Destinn about her work involving the cinema. ${ }^{59}$ Emil Focht (1864-1954), a former actor at the National Theatre, assisted Maturová with management of the cinema. Their first artistic encounters took place in 1916 in the play Invitation to the Dance and in 1921 in the film Kriz u potoka (The Cross by the Brook). In the singer's album there are two pictures of them together $[161,230]$. Maturová served as the director ${ }^{60}$ of this self-help enterprise until she died suddenly on 25 February $1938 .{ }^{61}$

Růžena Maturová demonstrated her acting talent right after the founding of Czechoslovakia in yet another artistic field. Between 1920 and 1922, she appeared in silent films six times, although mostly in supporting roles: the mother of the chauffer Jaroslav Král (Legionár, 1920), the wife of a Russian landowner (Za čest vitězů, 1920), the miller's wife and mother of Viktorka (Babička, 1921), the miller's wife (Křžz u potoka, 1921), the widow Grundová (Mrtví žijí, 1922), and a woman (Koryatovič, 1922). Maturová also appeared on camera together with her friend and colleague Emil Focht, whom we have already mentioned, and in 1920 with the legendary Smetana tenor Adolf Krössing. ${ }^{62}$ The most valuable pictorial documentation of her work in film are 63 photographs from four films, ${ }^{63}$ accounting for more than a quarter of the photographs from Růžena Maturovás album. When working with shots on location, most of which are taken in reportage style (live), it has been possible in nearly every case to determine the important data (title of the film, casting of the main roles, dating), although the photographs bear no inscriptions from Maturová. From the film Babička (Grandmother), which is the first adaptation of Božena Němcovás novel, there are thirteen fascinating still shots of Anna Vaicová-Brabcová with Maturová depicting the relationship between Viktorka and her mother. Also fascinating are the pictures of Nataša Cyganková in the role of the miller's foster child Eva and Maturová in the role of the miller's wife in the film Legionár.

58) The same letter; see footnote no. 55.

59) "I'm busy with the cinema from 6 in the morning until 12 o'clock at night. [...] But we have the biggest and best cinema in Prague. It is known that we sing and do recitations there. [...] I've got a very good orchestra, but it's expensive. [...] Besides film, I show photographs of artists, composers, and librettists. On the programme this week is the $1^{\text {st }}$ performance of The Bartered Bride. [...] They are singing your songs [Zahrada srdce - Garden of the Heart] on the next programme." Undated letter NM-HM, Theatre Department H6E-1989.

60) TEICHMAN, Josef: Postavy českého divadla a hudby (Figures of Czech Theatre and Music), Orbis, Praha 1941, pp. 195 and 199.

61) Rủž. Maturová zemřela (Růž. Maturová Has Died), Národní listy, vol. 78, no. 56, Praha 26 Feb. 1938, p. 3: "Yesterday afternoon on the boulevard Revoluční near Štefánik Bridge, Růžena Maturová, the famous dramatic singer and former prima donna of Prague's National Theatre, was suddenly taken ill in a taxi. She was taken to Dr. Pelnár's clinic, where she died shortly thereafter.” Her grave is at the Olšany Cemetery (Olšany V., section 17, grave 27), where other members of Maturová's family and both of her husbands are laid to rest; the unobtrusive inscription reads: "Rủžena Maturová - an unforgettable Libuše".

62) In the film Legionár in the role of Count Otto Rosenberg. He is shown in the photograph with Maturová walking on the banks of the Vltava near the National Theatre. ČÁSLAVSKÝ, Karel: Tváre před kamerou (Faces before the Camera), Mht, Hořovice 1996, p. 92.

63) In the NFA collection of photographs with shots from Czech films, there are publicity stills from all six of the films mentioned here. In the large majority of cases, these are entirely different shots from those in Rủžena Maturová's album, and it can be deduced that more than one photographer was at work capturing the protagonists in action from various angles. 


\section{The film credits of Růžena Maturová with reference to her album compiled on the basis of available information ${ }^{64}$}

\begin{tabular}{|c|c|c|c|c|c|}
\hline Film title & Year & Based on / Subject & Director & Maturová's role & \begin{tabular}{|l} 
Photo \\
number in \\
the album \\
\end{tabular} \\
\hline $\begin{array}{l}\text { Legionáŕr (The } \\
\text { Legionnaire) }\end{array}$ & 1920 & $\begin{array}{l}\text { Original film story by } \\
\text { Antonín Ludvík Havel }\end{array}$ & Rudolf Měšták & \begin{tabular}{|l} 
Jaroslav's \\
mother
\end{tabular} & $190-214$ \\
\hline $\begin{array}{l}\text { Za čest vítězů } \\
\text { (In Honour of } \\
\text { the Victorious) }\end{array}$ & 1920 & $\begin{array}{l}\text { Original film story by } \\
\text { Antonín Ludvík Havel }\end{array}$ & \begin{tabular}{|l|} 
Antonín Ludvík \\
Havel, Julius Lébl
\end{tabular} & $\begin{array}{l}\text { Šokolov's wife, } \\
\text { wife of a Russian } \\
\text { landowner } \\
\end{array}$ & \\
\hline $\begin{array}{l}\text { Babička } \\
\text { (Grandmother) }\end{array}$ & 1921 & $\begin{array}{l}\text { Based on } \\
\text { Božena Němcová's } \\
\text { novel Babička }\end{array}$ & Thea Červenková & $\begin{array}{l}\text { The miller's wife } \\
\text { and Viktorka's } \\
\text { mother }\end{array}$ & $\begin{array}{l}164-189, \\
222\end{array}$ \\
\hline $\begin{array}{l}\text { Kríž u potoka } \\
\text { (The Cross by } \\
\text { the Brook) }\end{array}$ & 1921 & $\begin{array}{l}\text { Based on } \\
\text { Karolína Světlá's novel } \\
\text { Kř́ž u potoka }\end{array}$ & Jan S. Kolár & The miller's wife & $\begin{array}{l}160,215, \\
215 a, 216, \\
216 a-219, \\
223\end{array}$ \\
\hline $\begin{array}{l}\text { Mrtví žijí } \\
\text { (The Dead are } \\
\text { Living) }\end{array}$ & 1922 & $\begin{array}{l}\text { Based on } \\
\text { Karel Dewetter's novel } \\
\text { Mrtví žijí }\end{array}$ & Jan S. Kolár & $\begin{array}{l}\text { The widow } \\
\text { Grundová }\end{array}$ & 220,221 \\
\hline Koryatovič & 1922 & $\begin{array}{l}\text { Original film story by } \\
\text { Karel Figdor }\end{array}$ & Jan Just-Rozvoda & A women & \\
\hline
\end{tabular}

\section{Conclusion}

The album is a valuable acquisition for the collection of the Bedřich Smetana Museum and in particular for research on Růžena Maturová. It mirrors the course of her career from 1889 to 1910, but above all it has shed light on the period of her life after her career at the National Theatre ended (1910-1938). This research of iconography has revealed the singer to us in a broad range of activities: in music theatre, in films, and even as nurse or when taking the initiative in other cultural activities for retired soloists from the National Theatre in Prague. In view of the fact that the only monograph about Maturová was written in 1936, the time is past due to deal with her from the perspective of current musicology and in a broader interdisciplinary context.

Address: Jana Plecitá, Muzeum Bedřicha Smetany, Novotného lávka 1, 11000 Praha 1, Czech Republic E-mail: jana.plecita@nm.cz

64) Filmový prehled (Film Review). The internet portal of the Czech National Film Archives, following in the tradition of a monthly journal with the same title, which was published in hard copy from 1950 to 2013. Accessed from: https://www.filmovyprehled.cz/cs [accessed on 27 Mar. 2020]. Český hraný film I (Czech Feature Film I): 1898-1930, Národní filmový archiv (National Film Archives), Praha 1995. Accessed from: http://web.nfa.cz/CeskyHranyFilm [accessed on 27 Mar. 2020]. Filmová databáze. Accessed from: www.fdb. cz [accessed on 27 Mar. 2020]. Česko-Slovenská filmová databáze (Czech-Slovak Film Database). Accessed from: www.csfd.cz [accessed on 27 Mar. 2020]. 


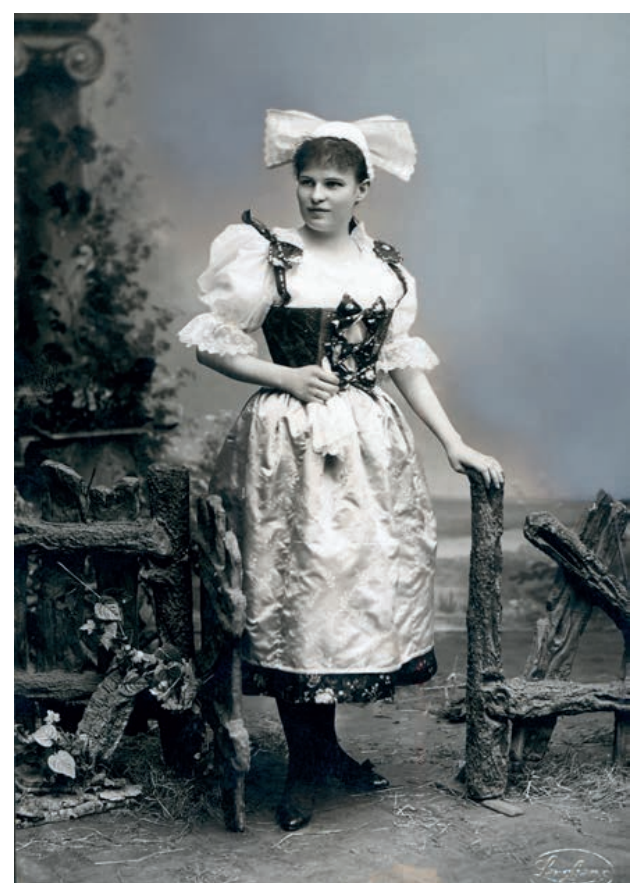

Růžena Maturová as Mařenka in Smetana's opera The Bartered Bride / Růžena Maturová jako Mařenka ze Smetanovy opery Prodaná nevěsta Photograph, J. F. Langhans, Prague, 1893 /

Fotografie, J. F. Langhans, Praha, 1893 NM-CMH-MBS inventory no. / inv. č. 3212/2

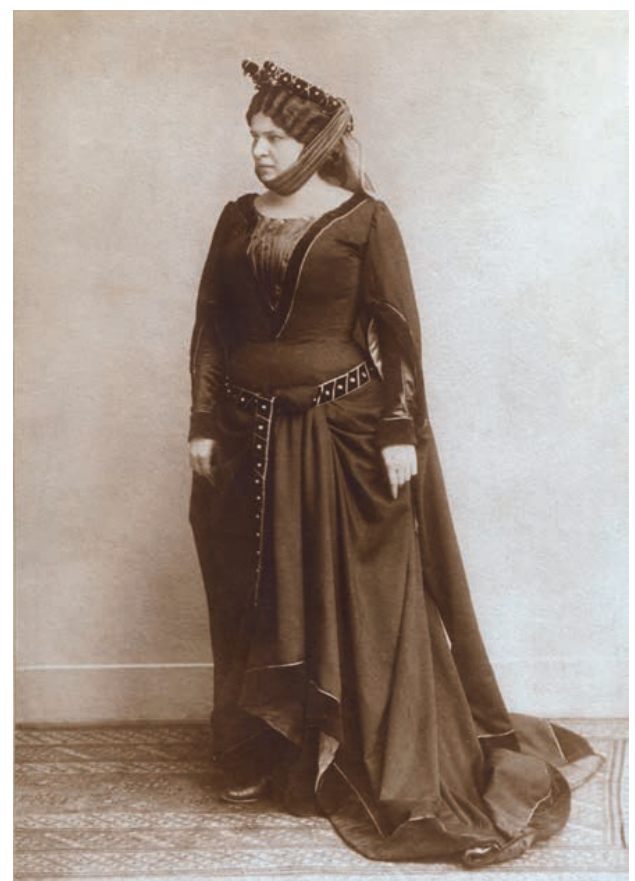

Růžena Maturová as Milada in Act I of Smetana's opera Dalibor / Růžena Maturová jako Milada z 1. jednání Smetanovy opery Dalibor Photograph, J. F. Langhans, Prague, 1900 / Fotografie, J. F. Langhans, Praha, 1900 NM-CMH-MBS inventory no. / inv. Č. 1930

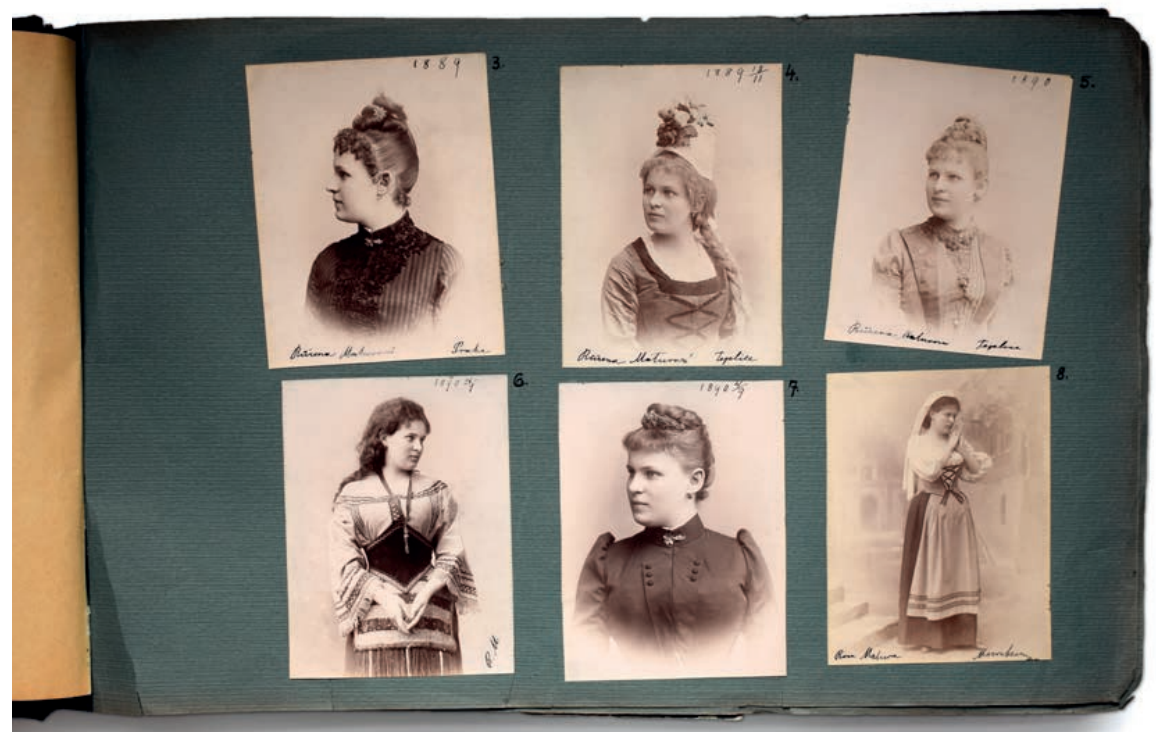

Růžena Maturová's photo album / Ukázka fotoalba Růženy Maturové NM-ČMH-MBS inventory no. / inv. č. 3212/3-8 


\section{Obraz osobnosti Rưženy Maturové v ikonografické sbírce Muzea Bedřicha}

\section{Smetany}

\section{Jana Plecitá}

Muzeum Bedřicha Smetany (dále MBS) se může pochlubit bohatou fotografickou sbírkou, v níž se nacházejí snímky různé povahy. Od začátku existence muzea se rozšiřovaly jeho jednotlivé fondy také díky darům. Zaměříme-li se na portrétní fotografie, které tvoří zejména vizitkové a kabinetní snímky, podařilo se během prvních desetiletí nashromáždit kromě portrétů Bedřicha Smetany, jeho rodiny a dalších osobností i podobizny operních pěvců, a to nejen ve formě civilních portrétủ, ale také v kostýmech smetanovských a jiných rolí.

Osobnost, na niž je v současné době zaměřen výzkum a odborné zpracování fotografického fondu ikonografických sbírek, Rủžena Maturová (1869-1938), je považována za jednu z nejslavněǰsích pěvkyň v historii opery Národního divadla. Hned tři měsíce po úmrtí Růženy Maturové byl fotografický fond MBS obohacen o tři rozsáhlá alba a sedmnáct samostatných fotografií, které v květnu 1938 odevzdal notář Ladislav Kuna jako odkaz pěvkyně muzeu. ${ }^{1}$ Kromě toho Růžena Maturová ve své závěti ${ }^{2}$ odkázala Ústřední jednotě českého herectva pozemek v Tróji a Moderní galerii (dnes Národní galerie v Praze) portrét od Maxe Švabinského. ${ }^{3}$ První album fotografií, které je předmětem tohoto článku, nese název R. Maturová. ${ }^{4}$ Další dvě alba jsou opatřena tituly Členové opery a baletu Národního divadla ${ }^{5}$ a Členové činohry Národního divadla. ${ }^{6}$ Ještě předtím, v roce 1931, Maturová věnovala

Předložená práce vznikla za finanční podpory Ministerstva kultury v rámci institucionálního financování dlouhodobého koncepčního rozvoje výzkumné organizace Národní muzeum (DKRVO 2019-2023/22.I.a, 00023272). 1) NM-ČMH-MBS č. př. F 106, zapsáno 31. 5. 1938. Maturová zemřela 25. února. Je přiložen dopis, ve kterém Kuna sděluje: „Dovoluji si vám odevzdati alba, která vám odkázala paní Růžena Maturová-Jílková, emer. členka opery Národního divadla v Praze, o čemž jsem vám podal sdělení dopisem ze dne 19. května t. r."

2) Odkazy pí. R. Maturové, Národní listy, roč. 78, č. 57, Praha 27. 2. 1938, s. 3.

3) Olej na plátně, $85 \times 84$ cm, Národní galerie Praha, inv. č. 03602 .

4) NM-ČMH-MBS inv. č. 3212/1-236.

5) NM-ČMH-MBS inv. č. 3213/1-319.

6) NM-ČMH-MBS inv. č. 3217/1-247. 
Smetanovu muzeu šest fotografií, ${ }^{7}$ v roce 1934 dvě kabinetky ${ }^{8}$ (v rolích Mařenky a Libuše), v roce 1937 vizitku Bedřicha Smetany s jeho přípisem a dva programy Prodané nevěsty v Berlíně 1893. ${ }^{9}$ Láskou umělkyně ke Smetanovi patrně možno vysvětlit, proč odkázala tyto materiály právě Muzeu Bedřicha Smetany. Ve sbírce muzea se nacházejí i další fotografie, dopisnice a tisky portrétů pěvkyně, vázané album s fotografiemi umělců Národního divadla (dále ND) ${ }^{10}$ a portrét Maturové v kostýmu Libuše od Alexe Adolfa Jelínka. ${ }^{11}$

Pracovním výstupem tohoto výzkumu je katalog ${ }^{12}$ zahrnující podrobně pouze album nazvané R. Maturová, obě další alba figurují v celkovém soupisu. Při identifikaci neurčených portrétů, fotografických ateliérů, datací a provenience jsem pracovala se zmíněnými třemi alby a s daty z fotografických fondů Národního muzea. ${ }^{13}$ Čerpala jsem však i z dat, která mi poskytl Langhans Archiv Praha (dále LAP), ${ }^{14}$ Archiv Národního divadla (dále AND), ${ }^{15}$ Národní filmový archiv (dále NFA), dále periodika Národní album, ${ }^{16}$ Zlatá Praha, ${ }^{17}$ Světozor ${ }^{18}$ a Český svět. ${ }^{19}$ Pokud jde o biografická data, opírala jsem se o jedinou existující monografii Artuše Rektoryse ${ }^{20}$ která vyšla ještě za života Maturové, takže hodnověrnost poskytnutých informací lze hodnotit poměrně vysoko. Práce tedy přináší souhrnný pohled na celoživotní umělecké aktivity umělkyně, opírající se zčásti o data Artuše Rektoryse, ${ }^{21}$ ale zejména o fakta, která lze vyčíst z fotografií: kompletní soupis operních rolí, přehled všech divadelních

7) NM-ČMH-MBS inv. č. 1929-1932, 2426, 2427.

8) NM-ČMH-MBS inv. č. 1933, 1934.

9) NM-ČMH-MBS inv. č. S 217/1746/4, programy č. př. F 9.

10) NM-ČMH-MBS inv. č. 4229/1-519.

11) Je to dar jejího synovce dr. Aloise Matury. Olej na plátně, 77 × 63,5 cm, NM-ČMH-MBS M 770. Předlohou byla fotografie NM-ČMH-MBS inv. č. 1929, původně z majetku Maturové.

12)Z důvodu rozsahu není součástí článku. Dostupné z: https://www.nm.cz/o-nas/odborna-cinnost\#katalogy 13) České muzeum hudby - Muzeum B. Smetany (NM-ČMH-MBS), České muzeum hudby - hudebněhistorické oddělení (NM-ČMH-HHO), České muzeum hudby - Muzeum A. Dvořáka (NM-ČMH-MAD), Sbírka Národního muzea - Divadelní oddělení.

14) V LAP se zachovalo 18 skleněných negativů Maturové.

15) V AND je uloženo album vázané v saténových deskách, obsahující větší kabinetky Maturové.

16) -Hda- [HEJDA, František Karel]: Růžena Maturová, in: Národní album. Sbírka podobizen a životopisů českých lidí prací a snahami vynikajících i zasloužilých, Jos. R. Vilímek, Praha 1899, il. J. Filipi, vyobrazení s. 11, medailon s. 17.

17) O. K.: Paní Růžena Maturová, Zlatá Praha, roč. 12, č. 12, Praha 1. 2. 1895, s. 142 (vyobrazení Maturové v roli Santuzzy, s. 133); Tři postavy poesie Puškinovy, Zlatá Praha, roč. 16, č. 30, Praha 2. 6. 1899, s. 356 (vyobrazení Maturové v roli Máši, ateliér $F$. J. Langhans).

18) -j.: Prodaná nevěsta v Berlíně, Světozor, roč. 27, č. 34, Praha 7. 7. 1893, s. 407-408; -j.: Růžena Maturová, Světozor, roč. 30, č. 25, Praha 1. 5. 1896, s. 298 (vyobrazení Maturové, ateliér Jan Mulač, s. 289).

19) REKTORYS, Artuš: Naše umělkyně Rủžena Maturová, Český svět, roč. 1, č. 8, Praha 17. 2. 1905, s. 258 (vyobrazení Maturové v roli Libuše, ateliér V. Donát, s. 257).

20) REKTORYS, Artuš: Růžena Maturová, O. Girgal, Praha 1936 (dále REKTORYS). Monografie je doplněna čtrnácti fotografickými reprodukcemi rolí Maturové, dvěma civilními fotografiemi a portrétem od Maxe Švabinského.

21) Přehled rolí REKTORYS, op. cit. v pozn. 20, s. 105-131. V několika př́padech se podařilo indentifikovat role tam, kde Rektorys mlčí. Opraven autor titulu Králova nevěsta (Robert Fuchs, zatímco u Rektoryse chybně uveden Richter, který byl dirigentem), dále opraven autor operety Kapitán Fracasse (Rudolf Dellinger, zatímco Rektorys uvádí libretistu Richarda Genée). 
i koncertních vystoupení, a to jak na německých scénách, tak v Rusku (Petrohrad, Moskva), ve Varšavě, v Bělehradě, v USA (New York, Chicago, Cedar Rapids, Cleveland, Omaha), a samozřejmě především v pražském Národním divadle ${ }^{22}$ i na jiných českých scénách.

\section{Fotoalbum R. MATUROVÁ}

Fotoalbum o rozměrech $53 \times 33 \times 7$ cm má koženou tmavohnědou vazbu zdobenou zlatými linkami po obvodu desek, na hřbetu je vyražen zlatý text a lyra. Obsahuje 63 folií a přední i zadní předsádku. Celkem 239 fotografií a tištěných reprodukcí je nalepeno jednostranně na 42 kartonů vyšší gramáže barvy šedozelené a 15 kartonů barvy cihlově červené, 6 kartonů je bez fotografií. Papír je velmi lámavý a fragilní. Jednotlivé kartony jsou proloženy tenčím světlým papírem. I přesto více než polovina fotografií vytvořila během času otisk na protilehlé straně kartonu. Navzdory tomu jsou fotografie v celkem dobrém stavu.

Číslování fotografií je průběžné takto: 1-80, 80a, 81, 81a, 82, 82a, 83-117, 118a, 118b, 119-215, 215a, 216, 216a, 217-236. Skutečný počet je tedy 242 fotografií. Album přišlo do sbírek MBS kompletní. ${ }^{23}$ Bohužel se dnes postrádají 3 fotografie. ${ }^{24} \mathrm{U}$ prvé jde o snímek Maturové v kostýmu Libuše z roku 1898 [1], ${ }^{25}$ u dalších dvou jde o pěvkyni v kostýmu Rusalky $[28,76]$ z ateliéru Langhans. V albu část fotografií obsahuje př́ípisy Růženy Maturové (perem či tužkou) s údaji o místě, roli, dataci či bližším označení osob. Rozměry jsou různé a neodpovídají údajům v inventární knize. Fotografie nezachovávají vždy chronologické pořadí. V katalogu jsou fotografie utř́děny podle těchto hledisek: podle rolí (opera 70, činohra 1), civilní snímky chronologicky (Maturová 48, skupiny osob 31), jiné osoby (16), film (63), budovy (6), dopisnice (3), jiné (1) a chybějící fotografie (3).

$\mathrm{Z}$ pražských fotografických ateliérů jsou $\mathrm{v}$ albu necelou polovinou zastoupeny ateliér Langhans ${ }^{26}$ a Josef Fiedler. ${ }^{27}$ Ze zahraničních ateliérů se dvěma desítkami představuje mannheimský ateliér Conrada Rufa. ${ }^{28}$ Solitérně se objevují ateliéry Jan Mieczkowski (Varšava), ${ }^{29}$

22) V Národním divadle (dále ND) působila od 19. 8. 1892 do 27. 8. 1893 jako host a od 14. 9. 1893 do 7. 2. 1910 jako člen.

23) Jak vyplývá ze zápisů v inventární knize, s. 164-170, kde jsou uvedeny stručné popisy včetně rozměrů.

24) Ke ztrátě došlo mezi lety 1975 až 1984 . V inventární knize jsou revizní razítka rev. 52, rev. 75 a v roce další revize 1984 razítko není.

25) Snímek je otištěn ve Vilímkově secesním Národním albu (viz pozn. 16) a v časopise Český svět (viz pozn. 19). Dokládají jej dvě kabinetky z ateliéru J. Tomáš, Praha (NM-ČMH-MBS F 4675/1 a NM-ČMH-MBS inv. č. 1934). Čísla v hranatých závorkách uvádějí pořadové číslo fotografie v albu.

26) Firma působila v letech ca. 1884-1919 na adrese Praha, Vodičkova 37. SCHEUFLER, Pavel: Fotografické ateliéry na území Koruny české, Národní památkový ústav, Praha 2017, s. 147 (dále SCHEUFLER).

27) Ateliér na adrese Praha, Václavské náměstí 24 od 13. 7. 1893 do 1. 2. 1921. Viz SCHEUFLER, op. cit. v pozn. 26, s. 95.

28) Mannheim, Breitestrasse M 1.4. Dostupné z: http://www.fotorevers.eu/de/fotograf/Ruf/55/ [cit. 27. 3. 2020].

29) Fotografické studio Jan Mieczkowski ve vlastním domě 1853-1889, Varsovie, Nowo Miosowa 1. Dostupné z: http://www.fotorevers.eu/fotograf/Mieczkowski/1284/[cit. 27. 3. 2020]. 
Josef A. Neuman (Praha), ${ }^{30}$ Václav Vlasák (České Budějovice) ${ }^{31}$ a poloamatérský fotograf Karel Váňa (Praha). ${ }^{32}$ Prvním známým portrétem je fotografie, která vznikla v roce 1889 v ateliéru Františka Šlechty [3]. ${ }^{33}$

Z pražské provenience nejsou zastoupeni nap̌r. Jan Mulač a Jan Tomáš, přestože si Maturová u nich snímky pořizovala. ${ }^{34} \mathrm{Z}$ ateliérů je lokalizováno, za situace, kdy pouze 10 fotografií nese označení ateliéru, celých $65 \%$. Druhou polovinu fotoalba tvoří amatérské snímky a filmové záběry.

V albu Maturové se českého repertoáru týkají necelé tři desítky fotografií, světového pak téměř čtyři desítky. Zdaleka nejde o všechny její role, které během svého života ztvárnila. Z celkového počtu 89 rolí je v albu 25, tedy téměř jedna třetina (viz tabulka). Většina zobrazených rolí pochází z angažmá v Národním divadle (80\%).

\section{Soupis rolí s odkazem na album Růženy Maturové}

\begin{tabular}{|l|l|l|l|l|l|}
\hline Role & Skladatel & Opera, opereta & Divadlo & $\begin{array}{l}\text { Fotografický } \\
\text { ateliér }\end{array}$ & Č́́slo fota v albu \\
\hline Anežka & B. Smetana & Dvě vdovy & ND & K. Váňa & 130 \\
\hline Armida & A. Dvořák & Armida & ND & Langhans & 111,112 \\
\hline Desdemona & G. Verdi & Otello & Mannheim & [C. Ruf] & 12, 13, 14, 19 \\
\hline Desdemona & G. Verdi & Otello & ND & J. Fiedler & $43,64,65,66$ \\
\hline Eva & J. B. Foerster & Eva & ND & Langhans & $91,94,105$ \\
\hline Hedy & Zd. Fibich & Hedy & ND & J. Fiedler & $75,80,81$ \\
\hline Libuše & B. Smetana & Libuše & ND & Langhans & 86 \\
\hline Manon Lescaut & G. Puccini & Manon Lescaut & ND & Langhans & $82 a$ \\
\hline Mařenka & B. Smetana & Prodaná nevěsta & ND & Langhans & $2,21,23,78$ \\
\hline Marguerite & Ch. Gounod & Faust & Teplice & nezjištěn & 4 \\
\hline Maruše & Ant. Smareglia & Istarska svatba & ND & J. Fiedler & 40,73 \\
\hline Máša & Ed. Nápravník & Dubrovskij & ND & J. Fiedler & 39,59 \\
\hline Máša & Ed. Nápravník & Dubrovskij & ND & Langhans & 57, 58, 60 \\
\hline Micaëla & Ch. Bizet & Carmen & Mannheim & C. Ruf & $8,18,20$ \\
\hline
\end{tabular}

30) Ateliér byl v Praze v Karlově ulici vedle Svatováclavské záložny. OCELÁK, Radek: Katalog české vizitkové fotografie, Rýmařov 2020. Verze 1.2 (zveřejněna 18. 3. 2020). Dostupné z: http://podoby-predku.cz/katalog-ceske-vizitkove-fotografie/ [cit. 27. 3. 2020].

31) V roce 1907 koupil Václav Vlasák fotoateliér od Antonína Pecha. Sídlil na rohu Žižkovy třídy (tehdy Schmelingovy) a Senovážného náměstí.

32) Byl členem opery a činohry ND. Jako fotograf zachytil řadu svých kolegů.

33) Praha, Žitná č. 12. Ateliér se podařilo zjistit z fotografie NM-ČMH-HHO F 535.

34) Role Milady (Smetana, Dalibor), J. Mulač, NM-HM, Divadelní oddělení H6E-38F485; role Amelie (Verdi, Un ballo in maschera), J. Mulač, NM-HM, Divadelní oddělení H6E-38F487; role Libuše (Smetana, Libuše), J. Tomáš, NM-ČMH-MBS inv. č. 1934. 


\begin{tabular}{|l|l|l|l|l|l|}
\hline Role & Skladatel & Opera, opereta & Divadlo & $\begin{array}{l}\text { Fotografický } \\
\text { ateliér }\end{array}$ & Č́́slo fota v albu \\
\hline Milada & B. Smetana & Dalibor & ND & Langhans & $83,95,96$ \\
\hline Ortrud & R. Wagner & Lohengrin & ND & Langhans & 37, 87, 88, 125 \\
\hline Rachel & J. F. Halévy & La Juive & ND & K. Váňa & 127,129 \\
\hline Rusalka & A. Dvořák & Rusalka & ND & Langhans & $106,107,108$ \\
\hline Santuzza & P. Mascagni & Cavalleria rusticana & Mannheim & {$[$ C. Ruf] } & 6,33 \\
\hline Šárka & Zd. Fibich & Š́rka & ND & Langhans & $89,90,131$ \\
\hline Tosca & G. Puccini & Tosca & ND & Langhans & $\begin{array}{l}100,101,102, \\
103,104\end{array}$ \\
\hline Undine & A. Lortzing & Undine & Mannheim & {$[$ C. Ruf] } & 9,11 \\
\hline Valentine & G. Meyerbeer & Les Huguenots & ND & J. Fiedler & 29, 41, 71, 92 \\
\hline Viktorka & Ant. V. Horák & Babička & ND & Langhans & 109,110 \\
\hline Vlasta & Ot. Ostrčil & Vlasty skon & ND & Langhans & $97,98,99$ \\
\hline
\end{tabular}

\section{Střípky ze života Růženy Maturové, poskládané z alba}

Růžena Maturová navštěvovala pěveckou školu manželů Loewových, vyhledávaných pražských učitelů zpěvu. Patřila k jejich nejvýznamnějším žačkám spolu s Emou Destinnovou (1878-1930), která byla její obdivovatelkou a přítelkyní. ${ }^{35}$ Fotografii své učitelky Marie Loewe-Destinn si Maturová vlepila do alba [85]. ${ }^{36}$ Její první štací bylo městské divadlo v Teplicích. ${ }^{37}$ Po Teplicích následovalo angažmá v Nationaltheater Mannheim ${ }^{38}$ a znamenalo i v soukromém životě Maturové velmi mnoho. Poznala tam svého prvého chotě, člena dvorní činohry, Ludvíka Schreinera (1864-1896). ${ }^{39}$ Jeho úmrtím po krátkém manželství ztratila Maturová prrítele a ušlechtilého člověka. V albu jsou dvě jejich společné fotografie, před svatbou 1891 [10] ${ }^{40}$ a z roku 1895 [62]. Na přání ředitele Národního divadla v Praze F. A. Šuberta se Maturová s Mannheimem rozloučila již na počátku roku 1893.

Než se v Národním divadle dostala Maturová k vlastnímu studiu rolí, zúčastnila se památného berlínského provedení Prodané nevěsty v létě 1893, odkud si přinesla nejen cenný úspěch, ${ }^{41}$ ale i zárodek obdivu ke Smetanově hudbě, jež se pak stala největší láskou

35) Ještě jako Kittlová věnovala Maturové v roce 1896 svazeček básní, nazvaný Hrstka rýmů. Svou fotografii v kostýmu Milady dedikovala „Paní Růženě Maturové v praátelském obdivu Emma Destinnová 1912“viz NMČMH-MBS inv. č. 3213/269.

36) Mezzosopranistka Marie von Dreger Loewe-Destinn (1837-1921) v roli Balkis (Gounod, La reine de Saba).

37) Od ř́jna 1889 do konce 1890.

38) Duben a záŕí 1890, září 1890 až leden 1893. Vystoupila ve 24 operních úlohách a 2 operetních.

39) Schreiner působil $v$ divadle v Mannheimu v letech 1870-1896. Zemřel v době, kdy již byla Maturová sólistkou ND v Praze.

40) Svatba se konala 18. října 1892 v Mannheimu.

41) „K stř́ídavému obsazení úloh připomínáme jen ještě krásný pondělní večer [3. 7. 1893], kdy pí Maturová i pan Burian př́mo koncertovali, a některá místa, tak zejména duetto Věrné milování přesným přednesem teprve přišla k platnosti." Prodaná nevěsta v Berlíně, Světozor, roč. 27, č. 34, Praha 7. 7. 1893, s. 408. Tamtéž 


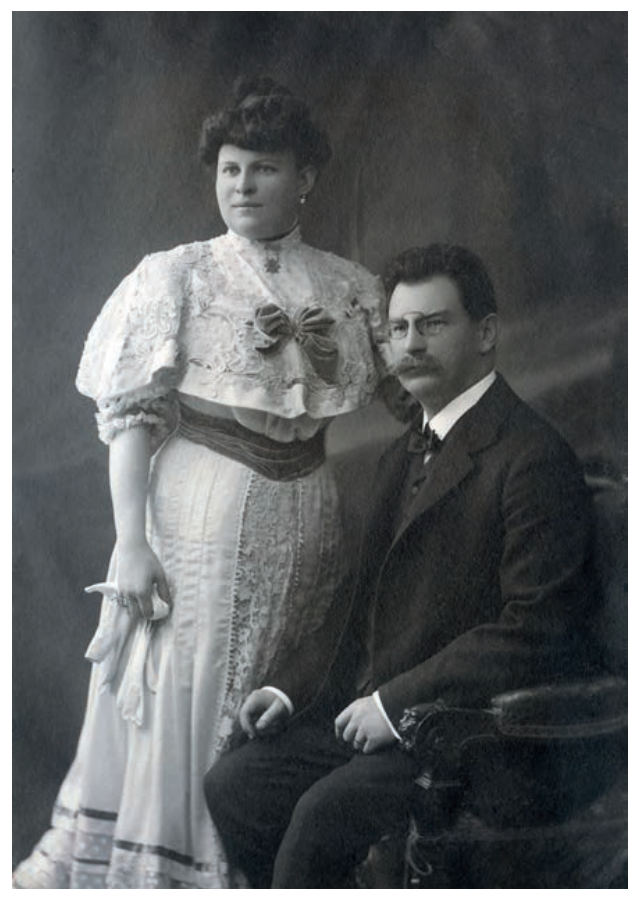

Růžena Maturová and František Jílek / Růžena Maturová a František Jílek

Photograph, J. F. Langhans, Prague, 1907 /

Fotografie, J. F. Langhans, Praha, 1907

NM-CMH-MBS inventory no. / inv. č. 3212/124 jejího života. ${ }^{42}$ Ředitel brněnského divadla Adolf Baumann ${ }^{43}$ zaměstnal české sólisty a zahájil řadu představení $\mathrm{v}$ divadle Unter den Linden. ${ }^{44}$ Pro tento účel vybral Prodanou nevěstu, jež si získala popularitu na Mezinárodní hudební a divadelní výstavě ve Vídni v roce 1892. Baumann získal dobrého kapelníka Františka Jílka (1865-1911), který byl krátce druhým manželem Růženy Maturové. ${ }^{45}$ Ve fotoalbu se zachovaly dva jejich společné snímky z roku 1907 [123, 124]. V Národním divadle se Maturová poprvé představila Mařenkou v říjnu 1893. ${ }^{46}$ Již v prvém roce svého zdejšího působení vytvořila také roli Milady, která v jejím repertoáru vykazuje největší počet provedení, což je téměř patnáctina všech vystoupení. Ve sbírce trojrozměrných předmětů MBS se dokonce dochovaly divadelní kostýmy, v nichž Maturová Miladu hrála. ${ }^{47}$ Za skutečnou raritu lze však považovat dokumentaci role Milady, kterou Maturová ztvárnila v Národním divadle roku 1900: je součástí sbírek MBS nejen ve fondu

na s. 407 fotografie účinkujících od F. J. Langhanse: Dopschová (Háta), Karel Burian (Jeník), Emanuel Kroupa (Krušina), Růžena Maturová (Mařenka), Hašek (Mícha), Martin Klein (Vašek), Josef Arden (Kecal) a Vítězslava Kratochvílová (Ludmila).

42) Smetana byl během její kariéry zastoupen šesti rolemi: Anežkou, kterou zahájila v zář́ 1893 své pražské angažmá. Pak následovaly Mařenka, Milada, Krasava, Libuše a Vendulka. Jejím nesplněným přáním byla Blaženka.

43) Baumann zamýšlel objet s Prodanou nevěstou, Hubičkou a Daliborem celou Evropu a Ameriku.

44) Režie Josef Šmaha, dir. Adolf Čech a František Jílek, choreografie Augustin Berger, výprava Roberta Holzera a balet byly přivezeny z Prahy. „Plánované osmitýdenní hostování, jež mělo pokračovat v Paříži a zejména v Americe, však skončilo po několika reprízách fiaskem kvůli organizačním nedostatkům, chybně vybranému termínu a špatnému [!] překladu Prodané nevěsty." (Jednalo se o překlad Maxe Kalbecka, který je dosud v německé jazykové oblasti spolu s modernějším překladem Kurta Honolky považován za nejlepší, a tedy nejfrekventovanější.) Dostupné z: http://encyklopedie.idu.cz/index.php/Baumann,_Adolf [cit. 27. 3. 2020]. Též PRAŽÁK, Přemysl: Smetanova Prodaná nevěsta, Lidová demokracie, Praha 1962, s. 294-296.

45) Svatba se konala v Praze 23. dubna 1906.

46) J. B. Foerster napsal o její Mařence in: Národní listy, roč. 33, č. 295, Praha 24. 10. 1893, s. 4: „[...] věc se osvědčila. Pěvkyně vypravila výkon značnou řadou jemně odpozorovaných detailů pěveckých $\mathrm{i}$ hereckých, dokázala, že je talentem tvưrčím; to váží nejvíce. Každé scéně dostalo se náležitého výrazu, vroucí oddanost milující dívky podána přirozeně, laškovné scény s Vaškem oživeny případnou hrou. Výborná disposice přičinila ostatní ku skvělému zevnějšímu úspěchu [...]“".

47) Bedřich Smetana, Dalibor, smuteční kostým z 1. aktu: NM-ČMH-MBS šaty TP 325, čelenka TP 326 a závoj TP 327. 


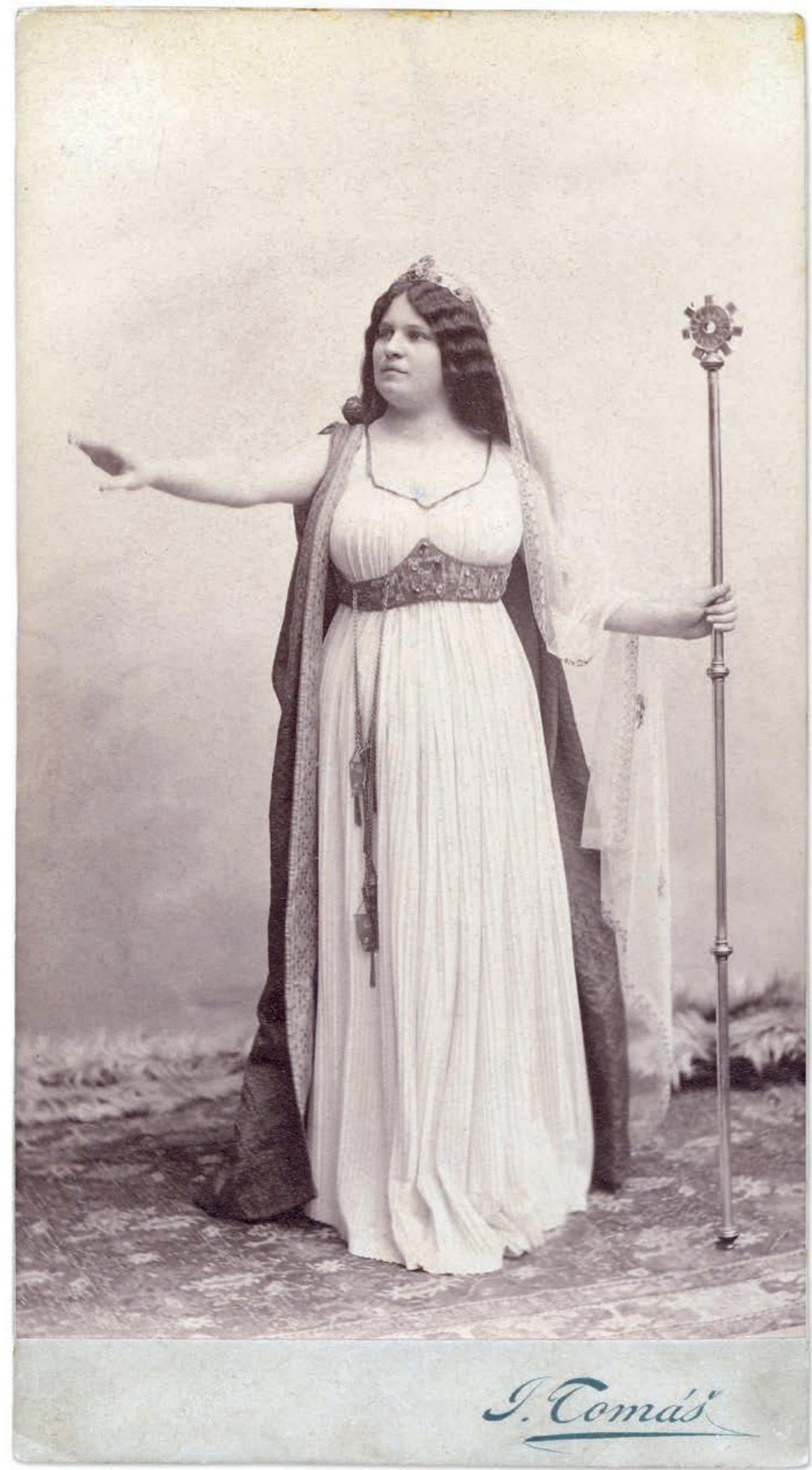

Růžena Maturová in the title role of Smetana's opera Libuše / Růžena Maturová jako Libuše ze stejnojmenné Smetanovy opery

Photograph, Jan Tomáš, Prague, 1898 / Fotografie, Jan Tomáš, Praha, 1898 NM-ČMH-MBS F 4675/2 


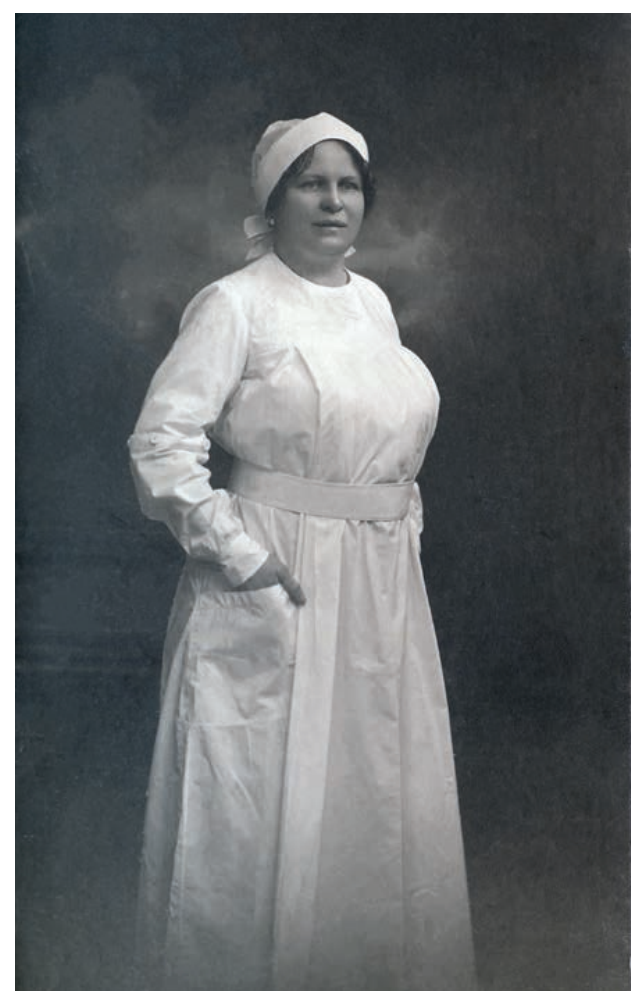

Růžena Maturová as a nurse / Růžena Maturová jako ošetřovatelka Photograph, J. F. Langhans, Prague, 1915 / Fotografie, J. F. Langhans, Praha, 1915 NM-CMH-MBS inventory no. / inv. č. 3212/150

fotografií, ale také scénografie a trojrozměrných předmětů. ${ }^{48}$

Roku 1897 se osmadvacetiletá Maturová dostala k úloze, která navždy zajistila její význam v české hudbě. Libuše tvoří vrchol její umělecké činnosti. Při jejím pátém uvedení 25. ledna 1898 obdržela Maturová od Družstva Národního divadla stříbrný věnec [146]. ${ }^{49}$ Gustav Salvayre, francouzský kritik a nadšený propagátor Smetanova díla ve Francii, nazval Maturovou „největši evropskou zpěvačkou“. Ema Destinnová prohlásila: „Po vás Libuši již nikdo neudělá, vy jste nejlepši Libuše." Adolf Čech jí věnoval klavírní výtah s dedikací: „Naši ideální Libuši k lask. upomince na dirigenta Smetanovy Libuše v upřimném přátelství Ad. Čech. ${ }^{50}$ Touto rolí se také 7. února 1910 rozloučila se scénou ND. ${ }^{51}$ Jediné vystoupení Růženy Maturové v činoherní roli komorné Rózy [235] ve hře Alexandra Dumase st. Vyzvání k tanci se konalo 9. prosince 1916.

Za svého hostování v Bělehradě v říjnu 1901 vystoupila Růžena Maturová na koncertě v budově dnešního Národního divadla [32]. V době návštěvy v Srbsku obdržela Ř́d svatého Sávy III. třídy, ${ }^{52} \mathrm{~s}$ nímž se nechala několikrát fotografovat u Langhanse ve Vodičkově ulici v Praze [77, 79, 128]. Její lidský charakter poznáme nejlépe z válečných let a z doby krátce po válce, kdy až do roku 1920 působila v nemocnici na Karlově náměstí jako ošetřovatelka. ${ }^{53}$ Z roku 1915 pocházejí dvě fotografie Maturové v úboru ošetřovatelky [150, 151].

48) Z kostýmu Milady z 2. aktu se zachovala halena NM-ČMH-MBS TP 323 podle kostýmního návrhu Karla Štapfera NM-ČMH-MBS Sc 0403.

49) Věnec s nápisem „Slovutné umělkyni Růženě Maturové Družstvo Národního divadla v Praze za skvělé zosobnění Smetanovy Libuše." (REKTORYS, op. cit. v pozn. 20, s. 45).

50) REKTORYS, op. cit. v pozn. 20, s. 45.

51) Nechala vytisknout pozvánky s textem „Růžena Maturová vzdává srdečný dík za milou a vzácnou vzpomínku, jakož i za laskavý projev účasti při jejím prèedstavení na rozloučenou." NM-HM, Divadelní oddělení H6E-35F17.

52) Řád svatého Sávy byl založen v roce 1883 srbským králem Milanem Obrenovićem. Byl udělován za umělecké, kulturní a vědecké zásluhy. Uděloval se i cizincům.

53) Její nemocní jí dali nejkrásnější titul, který láska může dát, říkali jí: „naše máma“. (REKTORYS, op. cit. v pozn. 20 , s. 62 ). 


\section{Růžena Maturová in film roles / Růžena Maturová ve filmových rolích}

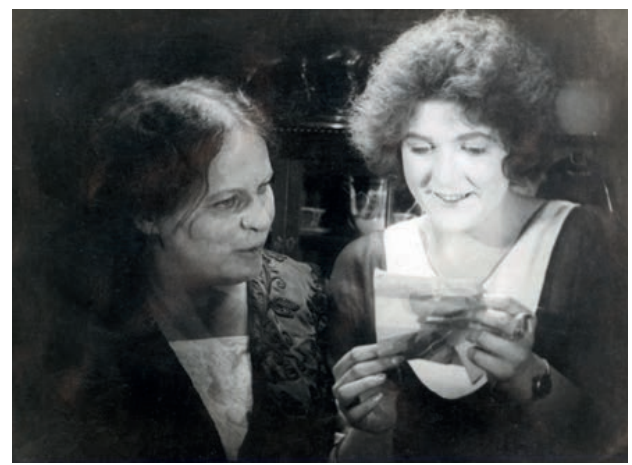

The Legionnaire / Legionář, 1920

NM-ČMH-MBS inventory no. / inv. č. 3212/200

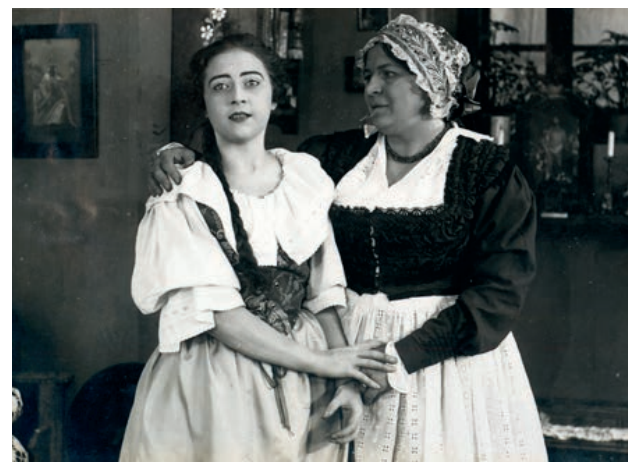

The Cross by the Brook / Kríž u potoka, 1921

NM-ČMH-MBS inventory no. / inv. č. 3212/218

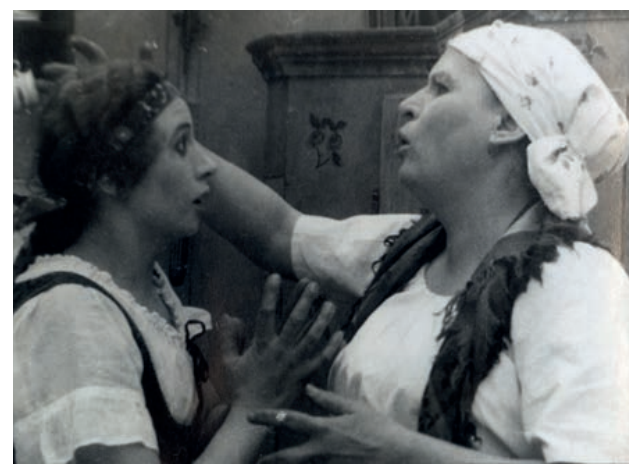

Grandmother / Babička, 1921

NM-ČMH-MBS inventory no. / inv. č. 3212/169

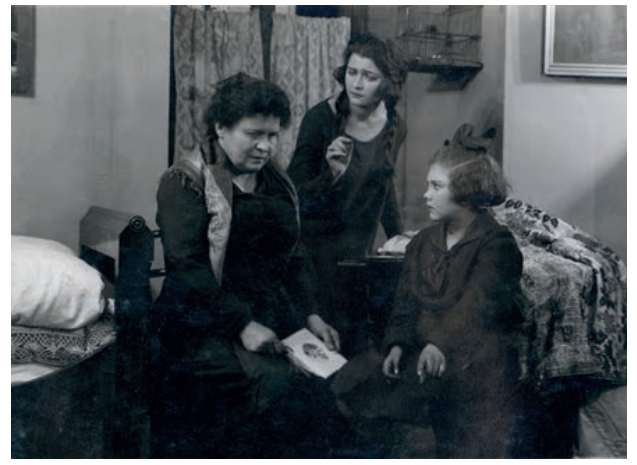

The Dead Are Living / Mrtví žijí, 1922

NM-ČMH-MBS inventory no. / inv. č. 3212/220

Hned po převratu 1918 věnovala Maturová všechnu svou energii tomu, aby prosadila přidělení populárního pražského biografu zvaného Na Slovanech, které bylo postaveno na místě Bia Imperial. ${ }^{54}$ Licence patřila Klubu penzionovaných sólistů Národního divadla v Praze. ${ }^{55}$ Z jeho výtěžků mělo být finančně pomáháno penzionovaným členům ND. A tato iniciativa přinesla úspěch, takže díky Maturové obdržel Klub penzistů ND celý 1 milion korun. ${ }^{56}$ V albu se dochovaly vzácné fotografie jak budovy kina [227], tak interiéru [159]. ${ }^{57}$ Pro prvé

54) Bio Imperial bylo zřízeno v roce 1911 v prostorách bývalého kina Illusion. V roce 1920 bylo zbouráno. Na jeho místě bylo postaveno nové kino nazvané Na Slovanech, jež mělo 900 míst. Bylo zničeno při americkém náletu 14. února 1945 současně s věžemi Emauzského kláštera. (ŠŤÁBLA, Zdeněk: Data a fakta z dějin čs. kinematografie 1896-1945, sv. 1, Čs. filmový ústav, Praha 1988, s. 149; dále ŠŤÁBLA).

55) O vzniku licence se Maturová zmiňuje v dopise Emě Destinnové ze dne 31. 8. 1920: „Klub penzionovaných sólistů Nár. divadla obdržel před půl druha rokem biografickou licenci, aby jejím výnosem zlepšil svým 32 členům, zasloužilým to starým umělcům činohry i opery Nár. divadla, dámám i pánům skrovné jich pensičky a trochu nahradil jim ztráty v době válečné je postihnuvší." NM-HM, Divadelní oddělení H6E-1900.

56) POSPÍŠIL, Miloslav: Zoperního Olympu - Pěvecké legendy 20. století, Brána, Praha 2009, s. 75.

57) Podle fotografie vchodu do bia Na Slovanech i fotografie jeho interiéru šlo spíše o adaptaci původního prostoru, nikoli o novostavbu. Viz ŠŤÁBLA, op. cit. v pozn. 54. 
představení měla Maturová v úmyslu uvést film Slavná Destinnová v svém domově, v zámku ve Stráži a zorganizovat natáčení slavné zpěvačky na Stráži, ${ }^{58} \mathrm{k}$ čemuž bohužel nedošlo. O své práci kolem biografu se svěřuje v dopise Emě Destinnové. ${ }^{99} \mathrm{~S}$ vedením kina Maturové pomáhal Emil Focht (1864-1954), bývalý činoherec ND. Umělecky se spolu setkali v roce 1916 ve hře Vyzvání $k$ tanci a v roce 1921 ve filmu Křiž u potoka. V albu pěvkyně jsou jejich dvě společné fotografie [161, 230]. U tohoto svépomocného podniku Maturová pracovala jako ředitelka ${ }^{60}$ až do své náhlé smrti 25 . února $1938 .{ }^{61}$

Herecký talent Růženy Maturové se projevil hned po vzniku Československa i v dalším uměleckém oboru. V letech 1920-1922 se šestkrát objevila v němém filmu, byt’ vesměs ve vedlejších rolích: matka řidiče Jaroslava Krále (Legionářr, 1920), žena ruského statkáře ( $Z a$ čest vitězů, 1920), mlynářka a matka Viktorky (Babička, 1921), mlynářka (Kř́ž u potoka, 1921), vdova Grundová (Mrtví žijí, 1922) a žena (Koryatovič, 1922). Maturová se před kamerou setkala i s již zmíněným přítelem a kolegou Emilem Fochtem a v roce $1920 \mathrm{~s}$ legendárním smetanovským tenorem Adolfem Krössingem. ${ }^{62}$ Pro obrazové zachycení její filmové práce je největším př́nosem 63 pracovních záběrů ze čtyř filmů, ${ }^{63}$ což je více než čtvrtina fotografií z alba Růženy Maturové. Při práci se záběry na place, jež mají převážně reportážní charakter, se téměř ve všech př́ípadech podařilo zjistit důležitá data (název filmu, obsazení hlavních rolí, datace), přestože fotografie neobsahují žádné přípisy Maturové. Z filmu Babička, který je prvním zpracováním románu Boženy Němcové, fascinuje třináct momentek Anny Vaicové-Brabcové s Maturovou, ztvárňující vztah mezi Viktorkou a její matkou. Podobně tomu je u snímků Nataši Cygankové v roli mlynářových schovanky Evy a Maturové v roli mlynářky z filmu Legionár̆.

58) Tentýž dopis, viz pozn. 55.

59) „Biograf mne zaměstnává od 6 ráno až do 12 večer. [...] Máme ale největší a nejlepší biograf v Praze. To se ví, že tam zpíváme a recitujeme. [...] Orkestr mám velice dobrý, ale také drahý. [...] Mimo film ukazuju fotografie umělců, komponistů a libretistů. Tenhle týden je na programu 1. predstavení Prodané nevěsty. [...] Př́ístí program se budou zpívat Vaše písně [Zahrada srdce]." Nedatovaný dopis NM-HM, Divadelní oddělení H6E-1989.

60) TEICHMAN, Josef: Postavy českého divadla a hudby, Orbis, Praha 1941, s. 195 a 199.

61) Růž. Maturová zemřela, Národní listy, roč. 78, č. 56, Praha 26. 2. 1938, s. 3: „V Revoluční třídě u Štefánikova mostu byla včera odpoledne náhle stižena nevolnostív autodrožce známá dramatická pěvkyně, bývalá primadona pražského Národního divadla, Růžena Maturová. Byla odvezena na kliniku prof. dr. Pelnáře, kde však zakrátko zemřela." Hrob na Olšanském hřbitově (Olšany V., odd. 17, hrob 27), kde jsou uloženi i další členové Maturovy rodiny i oba manželé pěvkyně, nese nenápadný nápis: „Růžena Maturová - nezapomenutelná Libuše“.

62) Ve filmu Legionář v roli hraběte Otto Rosenberka. Na fotografii s Maturovou při procházce na nábřeží u ND. ČÁSLAVSKÝ, Karel: Tváré prèed kamerou, Mht, Hořovice 1996, s. 92.

63) Ve sbírce fotografií NFA, obsahující záběry z českých hraných filmů, jsou zastoupeny i fotosky ze všech šesti zde zmiňovaných snímků. Přitom jde v naprosté většině případů o zcela jiné záběry, než které nabízí album Rủženy Maturové, z čehož lze usuzovat, že na place pracovalo více fotografů, zachycujících protagonisty vakci z různých úhlů. 


\section{Filmografie Růženy Maturové s odkazem na její album, sestavená na základě dostupných informací64}

\begin{tabular}{|c|c|c|c|c|c|}
\hline Název filmu & \begin{tabular}{|l|} 
Rok \\
výroby
\end{tabular} & Předloha / Námět & Režie & Role Maturové & $\begin{array}{l}\text { Číslo fota } \\
\text { v albu }\end{array}$ \\
\hline Legionáŕr & 1920 & $\begin{array}{l}\text { původní filmový námět: } \\
\text { Antonín Ludvík Havel }\end{array}$ & Rudolf Měšták & $\begin{array}{l}\text { Jaroslavova } \\
\text { matka }\end{array}$ & $190-214$ \\
\hline $\begin{array}{l}\text { Za čest } \\
\text { vítězů }\end{array}$ & 1920 & $\begin{array}{l}\text { původní filmový námět: } \\
\text { Antonín Ludvík Havel }\end{array}$ & $\begin{array}{l}\text { Antonín Ludvík } \\
\text { Havel, Julius Lébl }\end{array}$ & $\begin{array}{l}\text { Šokolova žena, } \\
\text { žena ruského } \\
\text { statkáře }\end{array}$ & \\
\hline Babička & 1921 & $\begin{array}{l}\text { předloha: } \\
\text { Božena Němcová } \\
\text { (Babička - román) }\end{array}$ & Thea Červenková & $\begin{array}{l}\text { Mlynářka a } \\
\text { matka Viktorky }\end{array}$ & $\begin{array}{l}164-189 \\
222\end{array}$ \\
\hline Kř́ž u potoka & 1921 & $\begin{array}{l}\text { předloha: Karolína } \\
\text { Světlá (Kř́žz u } \\
\text { potoka-román) }\end{array}$ & Jan S. Kolár & Mlynářka & $\begin{array}{l}160,215, \\
215 a, 216, \\
216 a-219, \\
223\end{array}$ \\
\hline Mrtví žijí & 1922 & $\begin{array}{l}\text { předloha: Karel } \\
\text { Dewetter (Mrtví } \\
\text { žijí - román) }\end{array}$ & Jan S. Kolár & Vdova Grundová & 220,221 \\
\hline Koryatovič & 1922 & $\begin{array}{l}\text { původní filmový námět: } \\
\text { Karel Figdor }\end{array}$ & Jan Just-Rozvoda & žena & \\
\hline
\end{tabular}

\section{Závěr}

Album je cennou akvizicí nejen pro sbírku Muzea Bedřicha Smetany, ale zejména pro výzkum osobnosti Růženy Maturové. Zrcadlí její uměleckou dráhu v letech 1889-1910, především však osvětlilo období jejího života po ukončení kariéry v Národním divadle (19101938). Tento výzkum ikonografie nám ukázal osobnost zpěvačky v široké škále uplatnění: v hudebním divadle, ve filmu, ale i jako zdravotnice nebo iniciátorky dalších kulturních aktivit pro pensionované sólisty Národního divadla v Praze. Vzhledem k tomu, že jediná monografie o Maturové byla napsána v roce 1936, je více než aktuální zabývat se její osobností z pohledu současné muzikologie i v širším mezioborovém kontextu.

Adresa: Jana Plecitá, Muzeum Bedřicha Smetany, Novotného lávka 1, 11000 Praha 1, Česká republika E-mail: jana.plecita@nm.cz

64) Filmový prèhled. Internetový portál Národního filmového archivu o českém filmu navazující na měsíčník, který vycházel v tištěné podobě v letech 1950-2013. Dostupné z: https://www.filmovyprehled.cz/cs [cit. 27. 3. 2020]. Český hraný film I: 1898-1930, Národní filmový archiv, Praha 1995. Dostupné z: http://web. nfa.cz/CeskyHranyFilm [cit. 27. 3. 2020]. Filmová databáze. Dostupné z: www.fdb.cz [cit. 27. 3. 2020]. ČeskoSlovenská filmová databáze. Dostupné z: www.csfd.cz [cit. 27. 3. 2020]. 